\title{
Nano-structure of the Cristobalite and Tridymite Stacking Sequences in the Common Purple Opal from the Gevrekseydi Deposit, Seyitömer-Kütahya, Turkey
}

\author{
MURAT HATIPOGLU ${ }^{1,2 *}$, YASAR KIBICl ${ }^{3}$, GURSEL YANIK ${ }^{3}$, \\ CAFER OZKUL ${ }^{3}$, MEHMET DEMIRBILEK ${ }^{3}$ and YASEMIN YARDIMCI ${ }^{1}$
}

'Dokuz Eylul University, IMYO, Izmir Multidisciplinary Vocational School,

Gemmology and Jewellery Programme TR-35380 Buca-Izmir, Turkey.

${ }^{2}$ Dokuz Eylul University, The Graduate School of Natural and Applied Sciences,

Natural Building Stone and Gemstone Programme TR-35370 Buca-Izmir, Turkey.

${ }^{3}$ Dumlupinar University, Faculty of Engineering, Department of Geological

Engineering TR-43100 Kampus, Kutahya, Turkey.

${ }^{*}$ Corresponding author E-mail: murat.hatipoglu@ deu.edu.tr

http://dx.doi.org/10.13005/ojc/310104

(Received: January 15, 2015; Accepted: February 10, 2015)

\begin{abstract}
The strata that include the fine purple opal formations examined in this paper from the magmagenetic hydrothermal dissolutions. The opals are locally known as Gevrekseydi purple opals. These opal-bearing strata are deposited in volcanic lavas and tuffs in the SeyitömerKütahya region of western Turkey. The purple opals are common-type and attractive gem-quality, and they are sold on the worldwide gem markets. We conducted mineralogical investigations to clarify their silica building components, measure their nano-size, and determine their origins. The opals are an opal-CT (opal-cristobalite/tridymite)- type silica polymorph with the variable number of cristobalite and tridymite layers. The cristobalite and tridymite stacking sequences were evaluated in terms of maturation, crystallite size, and genesis of the opaline silica material. These sequences are modelled using X-ray diffraction patterns. The relationship between the crystallite size and full width at half maximum values of the Gevrekseydi purple opals were also examined using X-ray diffraction patterns. The crystallite sizes were found to be $L=17 \mathrm{~nm}$ for the main opal-CT peak (4.09 $\AA$ ), $L=23 \mathrm{~nm}$ for the shoulder opal-CT peak (4.29 $\AA$ ), and $\mathrm{L}=27 \mathrm{~nm}$ for the opal-CT/C peak $(2.51 \AA)$. Given the relationship between the crystallite size and maturation of opal-CT, the Gevrekseydi volcanic common purple opals are most likely in a stage of early to mid maturation
\end{abstract}

Key words: Gevrekseydi common purple opals, XRD, Opal-CT, Kütahya-Turkey.

\section{INTRODUCTION}

The gemmological classification of opal as precious, common, or hyalite (semi-precious) is based on whether the opal shows a play-of-color phenomenon caused by visible light diffraction on the stacking and whether it is transparent and vividly colored. An opal without play-of-color or vivid colors 
is called a common (semiprecious) opal. Precious opals are widely known as either sedimentary opaque-translucent black and white opals or volcanic transparent-translucent fire opals (JONES \& SEGNIT 1971, 1972; NAGASE \& AKIZUKI 1997). However, the common or hyalite opals have the more varied origins. They occur as sedimentary or volcanic rocks as well as volcaniclastic sediments, and are almost entirely opaque. Their appearance and colors are caused by their absorbance and by the inclusion of some metal transition trace elements (LEECHMAN 1975, FLÖRKE et al. 1991, ELZEA \& RICE 1996, FRITSCH et al. 2002). In this study, we are interested in a sample of gem-quality, volcanic common opals with an attractive purple coloration (Fig. 1). However, some of the materials of biogenic origin or the concretions (such as diatomites and geyserites) are described as "opaline silica", instead of as "opal" (JONES \& SEGNIT 1971).

Many of the common opals, of course, have significant commercial value (GAILLOU et al. 2008). Common colored opals have been mined worldwide. These include purple opals from Mexican and the United States, blue-green opals from Peru, green opals from Tanzania and Brazil, yellow opals from Saint-Nectaire, France, pink opals from France, Peru and Mexico (SANDERS 1981, KOIVULA \& FRYER 1984, FRITSCH 1991, KOIVULA \& KAMMERLING 1991, KAMMERLING \& FRYER 1994, FRITSCH et al. 2002, FRITSCH et al., 2004, RONDEAU et al. 2004).

There is a significant body of research on common opals, that have attractive colors, because of their geological significance. Some common purple opals are mined in some parts of Mexico, and they are sold under the trade name "Morado" opal on the worldwide gem market, because they can be cut into the beautiful cabochons (ELSASS et al. 2000,, FRITSCH et al. 2004).

Accordingly, the present study is the first investigation of the gemmological and geological properties of an opaque-translucent common opal with attractive purple coloration. The opals described here originate a gem-quality common opal mine deposit in the Seyitömer (Kütahya) region in Turkey. The distinctive color of these opals is a vivid purple with swirls of white (Fig. 1). In addition, many samples are multicoloured with a range of colors from lilac to orange, some with whitish features, in the same deposit. Their structure is compact, without macroscopic inclusions. Therefore, the bulk specimens can be fashioned into cabochons, carvings, or slabs. Because the compact is hard enough to take a polish, the structure makes it a superb lapidary material. The gem's beauty is also notably more natural than the product of heating or irradiation, which adds to its appeal.

Therefore, this paper aims (1) to study the geological settling and petrological features of this new opal mine-field, (2) reveal the chemical, spectroscopic and microscopic mineralogical fingerprint of the purple opal, and (3) survey the often under-appreciated "common" opal and its versatility as a lapidary gem to identify their characteristics and compare them to other common purple opals.

\section{MATERIALAND METHODS}

Gem-quality purple common opals were obtained near the village of Gevrekseydi in the Seyitömer-Kütahya region in the western Turkey.

To verify that the rough opal samples were indeed a pseudo-crystalline (or para-crystalline) silica, gemmological (non-destructive) characterization tests were performed on representative samples. The tests were performed in the DGL-Gemmological Testing Laboratory at Dokuz Eylül University.

Mineralogical (destructive) tests were also performed. Polarizing microscope images of thin sections of the purple opals were obtained using an Olympus BX41 binocular polarizing microscope with a high-intensity $6 \mathrm{~V}, 30 \mathrm{~W}$ halogen light source combined with U-CPA and U-OPA optical systems, after thin sections of the samples had been mounted on glass lamellae. For the digital images, the microscopic magnification (MM) was $5 \mathrm{X}$ (a combined magnification of $0.5 \mathrm{X}$ objective and $10 \mathrm{X}$ ocular) under crossed nicols $(+\mathrm{N})$ (active polarizer and analyzer) and parallel nicols. Polarizing microscope investigations were performed in the Optical Mineralogy Laboratory of the Department of Geology at Dumlupinar University. 
Chemical analyses of the Gevrekseydi purple opals used X-ray fluorescence (XRF) for major oxides, inductively coupled plasma-atomic emission spectroscopy (ICP-AES) for trace elements, and WST-SIM (loss on igneous for whole rock package-XRF) to determine ignition losses. These analyses were performed, and certified with the code number "IZ11037803", under contract with the accredited ALS Chemex Laboratory in Canada.

The base silica-building components of the purple opals were detected using X-ray powder diffraction patterns of a Cubi-XRD device with a $\mathrm{Cu}$ tube and a graphic monochromator. The samples were analyzed with $\mathrm{Cu}$ radiation and a $0.3 \mathrm{~mm}$ collimator at atmospheric pressure for 10 minutes each, in the range between 5 and $70^{\circ} 2$-theta. The d-spacing $[\AA \AA]$ diffraction matching using the comparative matching technique is based on the positions of peaks with relative intensities of $\left(\mathrm{I} / \mathrm{I}_{\mathrm{o}}\right) \%$ e"1, 2-theta values below 70 degree, and a tolerance range of \pm 0.01 . The FWHM values were calculated using the Broker AXS diffract plus software. X-ray diffraction XRD patterns were taken in the Material Research Laboratory of the Bati Anadolu Cement Factory in Izmir.

The dispersive confocal micro-Raman spectroscopy of the purple opals was performed on a dark background at room temperature using a HORIBA Jobin Yvan Scientific XPLORA dispersive confocal micro-Raman spectrometer ( $\mathrm{DC} \mu \mathrm{RS})$ with a high-throughput integrated spectrograph. The spectrometer uses one laser excitation of approximately $532 \mathrm{~nm}$. The operating temperature is between 15 and $28{ }^{\circ} \mathrm{C}$. The operation features are as follows: 799.75 of spectro, 1.17066 of exposition, $1200 \mathrm{~T}$ of grating, 5 of accumulation, 500 of hole, 100 of slit, $50 \%$ filter, 11.4315 of spectrum width, 50X objective, and 1 binning. Spectral manipulation as baseline adjustment was carried out using the device's software. The Raman record was carried out in the DGL-Gemmological Testing Laboratory at Dokuz Eylül University.

\section{RESULTS AND DISCUSSION}

\section{Opaline material features}

To verify that the investigated rough opal samples were indeed a pseudocrystalline (or paracrystalline) silica variety, non-destructive gemmological characterization tests were performed on representative samples. First, the average specific gravity (SG) values of the eight representative samples were measured using an electronic balance scale (measurement sensitivity of 0.001) using an SG kit, based on the formula (SG $\left.=\mathrm{W}_{\text {air }} / \mathrm{W}_{\text {air }}-\mathrm{W}_{\text {water }}\right)$. The specific gravity values ranged from 2.14 and $2.17 \mathrm{gr} / \mathrm{cm}^{3}$. Second, because they are opaque, the optical character, optical sign, and refractive index values of the eight representative opal samples were determined via the spot method, using an Eickhorst SR/XS standard refractometer device with an optical contact liquid of $1.79 \mathrm{RI}$, and a quartz lamp with a wavelength of $589 \mathrm{~nm}$. The refractive index value of the purple opals was between $\mathrm{N}=1.428$ and 1.436. Third, ultraviolet (UV) luminescence excitation of the purple samples was observed using a System Eickhorst UV 240 shortwave $(255 \mathrm{~nm})$ and long wave (366 nm) 4W UV lamp. The samples are inert under UV beams. Thus, when the average specific gravity value 2.15 is considered along with the other verifying results, the investigated opal samples appear to have a typical pseudo- or paracrystalline structure (AREM 1987, ROSSMAN 1994, BACK \& MANDARINO 2008).

\section{Provenance, Geology, Petrology, and Genesis of the Opals}

The region surrounding the gem-quality common opal mine-deposit near the Gevrekseydi village was examined for its geological and petrological features. Western Turkey is dominated by large E-W grabens and a number of approximately N-S-trending grabens. The TavsanliKütahya zone has been the subject of several previous by geologists (LEBKUCHNER 1957, 1959, NEBERT 1961, KALAFATÇIOGLU 1962, OKAY 1981, VICIL 1982, BAS 1986, SARIYILDIZ 1987, YANIK 1997, OZGENC \& ILBEYLI 2008, TÜRKMENOGLU \& YAVUZ-ISIK 2008, ÖZBURAN \& GÜRER 2011, AKKIRAZ et al. 2012). Both Paleozoic metamorphic rocks and upper Cretaceous ophiolitic melange are found on the floor of the Seyitömer-Kütahya basin. Neogene volcanic and sedimentary rocks also occur in the region. However, the Upper Miocene to Lower Pleistocene volcanic rocks where the purple opalbearing in volcanics occurred. These volcanics are 
Table 1: Average bulk and trace element analyses of the Gevrekseydi common purple opals

\begin{tabular}{|c|c|c|c|c|c|}
\hline $\begin{array}{l}\text { Oxides } \\
\%\end{array}$ & $\begin{array}{c}\text { Instrument } \\
\text { (XRF) } \\
\text { Detection limits }\end{array}$ & $\begin{array}{l}\text { Sample } \\
\text { Purple } \\
\text { Opal }\end{array}$ & Elements & $\begin{array}{c}\text { Instrument } \\
\text { (ICP-AES) } \\
\text { Detection limits }\end{array}$ & $\begin{array}{c}\text { Sample } \\
\text { Purple Opal }\end{array}$ \\
\hline $\mathrm{SiO}_{2}$ & $0.01 \%$ & 86.86 & & & \\
\hline $\mathrm{Al}_{2} \mathrm{O}_{3}$ & $0.01 \%$ & 0.66 & $\mathrm{Al}$ & $10 \mathrm{ppm}$ & 3500 \\
\hline $\mathrm{Fe}_{2} \mathrm{O}_{3}$ & $0.01 \%$ & 2.31 & $\mathrm{Fe}$ & 10 ppm & 18000 \\
\hline \multirow[t]{2}{*}{$\mathrm{CaO}$} & $0.01 \%$ & 0.11 & $\mathrm{Ca}$ & $0.01 \%$ & 0.10 \\
\hline & & & & $10 \mathrm{ppm}$ & 1000 \\
\hline \multirow[t]{2}{*}{$\mathrm{MgO}$} & $0.01 \%$ & 0.16 & $\mathrm{Mg}$ & $0.01 \%$ & 0.06 \\
\hline & & & & 10 ppm & 600 \\
\hline \multirow[t]{2}{*}{$\mathrm{Na}_{2} \mathrm{O}$} & $0.01 \%$ & 0.05 & $\mathrm{Na}$ & $0.01 \%$ & 0.03 \\
\hline & & & & $10 \mathrm{ppm}$ & 300 \\
\hline \multirow{2}{*}{$\mathrm{K}_{2} \mathrm{O}$} & $0.01 \%$ & 0.08 & $\mathrm{~K}$ & $0.01 \%$ & 0.06 \\
\hline & & & & 10 ppm & 600 \\
\hline $\mathrm{Cr}_{2} \mathrm{O}_{3}$ & $0.01 \%$ & $<0.01$ & $\mathrm{Cr}$ & $1 \mathrm{ppm}$ & 15 \\
\hline $\mathrm{TiO}_{2}$ & $0.01 \%$ & 0.10 & $\mathrm{Ti}$ & $10 \mathrm{ppm}$ & 800 \\
\hline $\mathrm{MnO}$ & $0.01 \%$ & 0.02 & $\mathrm{Mn}$ & $5 \mathrm{ppm}$ & 206 \\
\hline $\mathrm{P}_{2} \mathrm{O}_{5}$ & $0.001 \%$ & 0.017 & $\mathrm{P}$ & $10 \mathrm{ppm}$ & 30 \\
\hline $\mathrm{SrO}$ & $0.01 \%$ & $<0.01$ & $\mathrm{Sr}$ & $1 \mathrm{ppm}$ & 21 \\
\hline $\mathrm{BaO}$ & $0.01 \%$ & $<0.01$ & $\mathrm{Ba}$ & 10 ppm & 150 \\
\hline LOI & $0.01 \%$ & 7.72 & & & \\
\hline \multirow[t]{22}{*}{ Total } & $0.01 \%$ & 98.09 & & & \\
\hline & & & $\mathrm{Ag}$ & $0.5 \mathrm{ppm}$ & 3 \\
\hline & & & As & 5 ppm & 17 \\
\hline & & & $\mathrm{Be}$ & 0.5 ppm & $<0.5$ \\
\hline & & & $\mathrm{Bi}$ & 2 ppm & 8 \\
\hline & & & $\mathrm{Cd}$ & 0.5 ppm & 1.3 \\
\hline & & & Co & 1 ppm & 3 \\
\hline & & & $\mathrm{Cu}$ & $1 \mathrm{ppm}$ & 2500 \\
\hline & & & $\mathrm{Ga}$ & 10 ppm & $<10$ \\
\hline & & & $\mathrm{La}$ & 10 ppm & $<10$ \\
\hline & & & Mo & $1 \mathrm{ppm}$ & 9 \\
\hline & & & $\mathrm{Ni}$ & $1 \mathrm{ppm}$ & $<1$ \\
\hline & & & $\mathrm{Pb}$ & $2 \mathrm{ppm}$ & 127 \\
\hline & & & $\mathrm{s}$ & $0.01 \mathrm{ppm}$ & 0.34 \\
\hline & & & $\mathrm{Sb}$ & $5 \mathrm{ppm}$ & $<5$ \\
\hline & & & Sc & $1 \mathrm{ppm}$ & $<1$ \\
\hline & & & Th & 20 ppm & $<20$ \\
\hline & & & $\mathrm{TI}$ & 10 ppm & $<10$ \\
\hline & & & $U$ & 10 ppm & $<10$ \\
\hline & & & V & $1 \mathrm{ppm}$ & 13 \\
\hline & & & W & 10 ppm & $<10$ \\
\hline & & & $\mathrm{Zn}$ & $2 \mathrm{ppm}$ & 317 \\
\hline
\end{tabular}


predominantly intermediate-felsic lavas and pyroclastics, as a W-E outcropping in the Tavsanli Zone.

Table 2: Summary of the XRD peak values of the pseudo-crystalline silica phases (Opal-CT and Opal-CT/C) of the Gevrekseydi common purple opals

the primary d-spacing: 4.09 $\AA$ (Opal-CT)

$2 \theta$ angle: 21.745

$\Delta^{\circ} 2 \theta\left(=d_{\alpha 1} \times 0.360^{\circ} 2 \theta\right.$ peak): 1.96

Shoulder-the primary d-spacing: $\sim 4.29 \AA$ (opal-

CT)

$2 \theta$ angle: 20.710

$\Delta^{\circ} 2 \theta\left(=\mathrm{d}_{\alpha 1} \times 0.480\right): 1.54$

the primary d-spacing: $\sim 2.69 \AA$ (Opal-CT/C)

$2 \theta$ angle: 33.240

$\Delta^{\circ} 2 \theta\left(=d_{\alpha 1} \times 0.180^{\circ} 2\right.$ è peak): 0.48

the primary d-spacing: $\sim 2.51 \AA$ (Opal-CT/C)

$2 \theta$ angle: 35.900

$\Delta^{\circ} 2 \theta\left(=d_{\alpha 1} \times 0.300^{\circ} 2 \theta\right.$ peak $): 0.75$

the primary d-spacing: $\sim 1.84 \AA$ (Opal-CT/C)

$2 \theta$ angle: 49.535

$\Delta^{\circ} 2 \theta\left(=d_{\alpha 1} \times 0.960^{\circ} 2 \theta\right.$ peak $): 1.77$

the primary d-spacing: $\sim 1.69 \AA$ (Opal-CT/C)

$2 \theta$ angle: 54.195

$\Delta^{\circ} 2 \theta\left(=d_{\alpha 1} \times 0.480^{\circ} 2 \theta\right.$ peak): 0.81

the primary d-spacing: $\sim 1.62 \AA$ (Opal-CT/C)

$2 \theta$ angle: 56.835

$\Delta^{\circ} 2 \theta\left(=\mathrm{d}_{\alpha 1} \times 0.960^{\circ} 2 \theta\right.$ peak): 1.56

the primary d-spacing: $\sim 1.45 \AA$ (Opal-CT/C)

$2 \theta$ angle: 64.285

$\Delta^{\circ} 2 \theta\left(=\mathrm{d}_{\alpha 1} \times 0.360^{\circ} 2 \theta\right.$ peak $): 0.52$
The volcanics occur as flowing units with thicknesses of $5 \mathrm{~m}$ to $25 \mathrm{~m}$. Petrographically, the lavas mainly consist of plagioclase, quartz, biotite, pyroxene, amphibole, and glassy matrix. They have aphanitic texture with grey color in fresh samples and with light-grey color in weathering (altered/ decomposed) samples. The volcanic tuffs are made of a combination of rock and mineral fragments (e.g. feldspar, quartz) in volcanic ash matrix. The rock fragments in the tuffs are predominantly volcanic and rarely sedimentary in origin. The lavas and tuffs show locally silica and clay minerals alteration zones. Thin sections of the purple opal show mostly negative elongation that are sometimes undulatorydamped, indicating the presence of cristobalite and tridymite like layers (opal-CT and opal-C) (PRETOLA 2001). They are referred to as pseudocrystalline (or para-) textures in this study (Fig. 2.A and 2.B).

The purple opal-bearing zone and its surrounding area were geologically re-mapped, which revealed that the fine purple opal strata become intensely clear on the field at the northeast of the village of Gevrekseydi in the region: such stones are therefore called Gevrekseydi opals. These opals are an attractive gem-quality common opal. The opals are deposited in the large strata of the volcanic tuffs. However, the main silica source of the opals is derived from the underlain rhyodacitic and dacitic rocks, and all of them are called the Gevrekseydi volcanics.

Table 3: Modelling the probable amount of tridymite of the Gevrekseydi common purple opals, According to the peak width of $20.710^{\circ} 2$, which represents the shoulder peak of Opal-CT (dValue = 4.29 $\AA$ ), and probable amount of tridymite (modified from GUTHRIE et al. 1995 and ELZEA \& RICE 1996)

\begin{tabular}{|c|c|c|c|}
\hline Sample & $\begin{array}{c}\text { Shoulder Opal-CTPeak } \\
\text { width: } 20.710^{\circ} 2 \theta d \text {-value: } 4.29 \AA\end{array}$ & Range & Percentage \\
\hline & & $\geq 0.050$ & $25-30 \%$ \\
\hline & & $0.050-0.100$ & $30-35 \%$ \\
\hline & & $0.100-0.150$ & $35-40 \%$ \\
\hline & & $0.150-0.200$ & $40-45 \%$ \\
\hline & & $0.200-0.250$ & $45-50 \%$ \\
\hline & & $0.250-0.300$ & $50-55 \%$ \\
\hline & & $0.300-0.350$ & $55-60 \%$ \\
\hline Gevrekseydi Purple Opal & 0.360 & $0.350-0.400$ & $60-65 \%$ \\
\hline
\end{tabular}


A fault zone that developed in the Gevrekseydi volcanics allowed the magmagenetic hydrothermal dissolutions to rise. After the silicate minerals were dissolved by a hydrothermal alteration in the rhyodacite and dacite, a silicic acid $\left(\mathrm{H}_{4} \mathrm{SiO}_{4}\right)$-rich fluid was released. Thus, the dissolved silicon ions were transported through the crack zone in the volcanics. These fluids then combined with ground water. However, because the Gevrekseydi volcanics do not have large pores and cavities, the silicic acid-rich hydrothermal fluids continued into the overlain tuffs, forming a colloidal silica gel and ultimately opal in a relatively low-pressure and lowtemperature environment with the requisite $\mathrm{pH}$ conditions. The silicic acid-rich solutions coagulated as pseudo-crystalline-structured opals of cryptocrystalline or crystalline structured silica varieties in the relatively cooled cavities and pores.
It is well known that the opals occur at temperatures below $100{ }^{\circ} \mathrm{C}$ and lower pressure conditions.

A range of opal colors have been observed in an investigated area. These levels were filled with the major purple and minor lilac, violet, and yellow colored opals. In addition, light, dark brown, white and pink opals are also exposed in the same area.

\section{Chemistry and Mineralogical Properties of Purple Opal} Chemical Analyses and Coloration

The average composition (Table 1) of the Gevrekseydi common purple opals are as follows; $\mathrm{SiO}_{2}(86.86 \%), \mathrm{Al}_{2} \mathrm{O}_{3}(0.66 \%), \mathrm{Fe}_{2} \mathrm{O}_{3}(2.31 \%), \mathrm{CaO}$ $(0.11 \%), \mathrm{MgO}(0.16 \%), \mathrm{Na}_{2} \mathrm{O}(0.05 \%)$, and $\mathrm{K}_{2} \mathrm{O}$ $(0.08 \%)$. In addition, some trace element concentrations (Table 1) are also very distinctive,

Table 4: Micro-Raman band positions $\left(\mathrm{cm}^{-1}\right)$ and assignments of the Gevrekseydi common purple opal

\begin{tabular}{|c|c|c|c|c|}
\hline Opal-CT & Opal-C & Inclusions & Mode Symmetry* & Assignment \\
\hline & & 65 & $E_{(L O+T O)}$ & Low Quartz \\
\hline & & 144 & $\mathrm{E}_{(\mathrm{LO}+\mathrm{TO})}$ & Low Quartz \\
\hline & 292 & & & Opal-CT/C \\
\hline 363 & & & V & Opal-CT \\
\hline \multirow[t]{7}{*}{404} & & & & Opal-CT \\
\hline & & 783 & $\mathrm{~V}$ & Transition Metal Molecules \\
\hline & & 829 & V & Transition Metal Molecules \\
\hline & & 911 & V & Transition Metal Molecules \\
\hline & & 961 & V & Transition Metal Molecules \\
\hline & & 1055 & $\mathrm{~V}$ & Carbonaceous Matter \\
\hline & & 1729 & V & Carbonaceous Matter \\
\hline
\end{tabular}

KINGMA \& HEMLEY 1994, GÖTZE et al. 1998, POP et al. 2004 and DUMANSKA-SLOWIK et al. 2013; DumanskaSlowik et al. ${ }^{67} \mathrm{~V}=$ Symmetric stretching-bending vibrations

such as $\mathrm{Cu}(2500 \mathrm{ppm}), \mathrm{Ti}(800 \mathrm{ppm}), \mathrm{Ba}(150 \mathrm{ppm})$, Zn (317 ppm), Mn (206 ppm), and Pb (127 ppm). The transition metal elements above are characteristic of the Gevrekseydi opals. The distribution of the elements is dictated especially by cristallo-chemical substitution in the pseudo crystalline structure. The trace elements are most likely derived from hydrothermal alteration of the rock-forming minerals in the primary source rocks, such as rhyodacite, dacite and tuffs of the Gevrekseydi volcanics.
The ICP-AES analysis suggests that purple coloration of the Gevrekseydi opals is due to the transition metals, i.e., the higher abundance of Fe, $\mathrm{Cu}, \mathrm{Zn}, \mathrm{Mn}$, and $\mathrm{Pb}$. However, the main determination of color in the opal is not only the iron ion content but also the copper and titanium ion contents. Similar elemental contents for the purplish coloration have been reported for some common purple opals from Mexico, which are sold under the trade name "Morado" opal on the worldwide gem market (GÜBELIN 1986; ELSASS et al. 2000; FRITSCH et al. 2004). 


\section{X-Ray Diffraction}

The XRD patterns of the opals do not show sharp diffraction peaks but rather a broad and diffuse reflection at approximately $21.5^{\circ}$ 2-theta with d-values between 4.0 and $3.8 \AA$. This broad peak is called the "glass-peak", because of its resemblance with the diffuse peak produced by glass and because it merges with the background without interruptions (DODONY \& TAKACS 1980, GHISOLI et al. 2010).

The XRD patterns belonging to the Gevrekseydi common purple opals are signed opal-
CT (Fig. 3). The main peak (4.09 $\AA$ ) on the representative pattern is relatively intense and has a broad diffraction band with $4.29 \AA$ peak on its shoulders. The main peak at $4.09 \AA$ is evidence of opal-CT. In particular, the higher d-value of the main peak $(>4.05 \AA$ ) and its shape comply with the definition of opal-CT, as do the peaks at $2.51 \AA$, $2.03 \AA$, and $1.62 \AA$, and the lack of peaks at $3.13 \AA$ and $2.84 \AA$ which are characteristic of opal- $C$ (MONROE et al. 1969, FLÖRKE et al. 1975, FLÖRKE et al. 1976, FLÖRKE et al. 1991, ELZEA \& RICE 1996, ESENLI et al. 2003, ESENLI \& EKINCISANS 2013,).
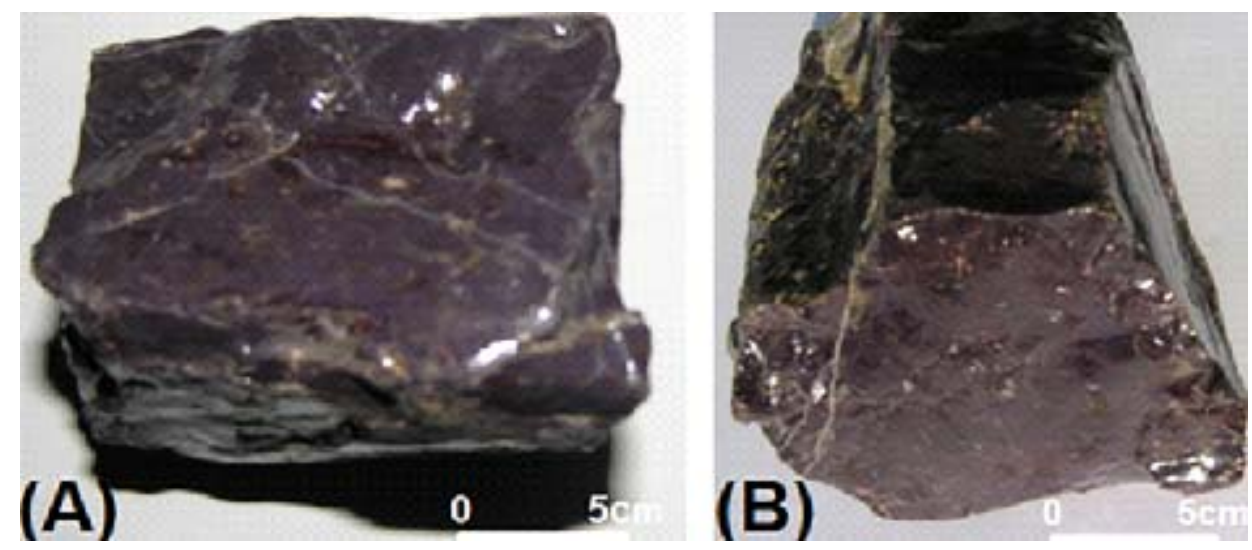

Fig. 1: Gem-quality common opal blocks, main part (A), and broken inner part (B). They are newly found in near the village of Gevrekseydi (Seyitömer-Kütahya, western Turkey), and display a vivid purple color with swirls of white

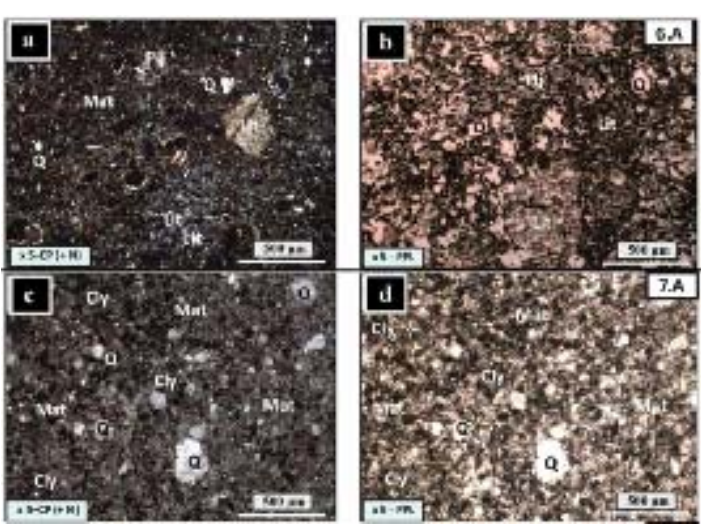

Fig. 2: A. Microphotos of the Gevrekseydi volcanic units and purple opals. 6.A -7.A: Rhyodacite /Dacite, (Q: Quartz, PI: Feldspar, Cly: Clay minerals, Mat; Matrix, Lit: Litic materials)
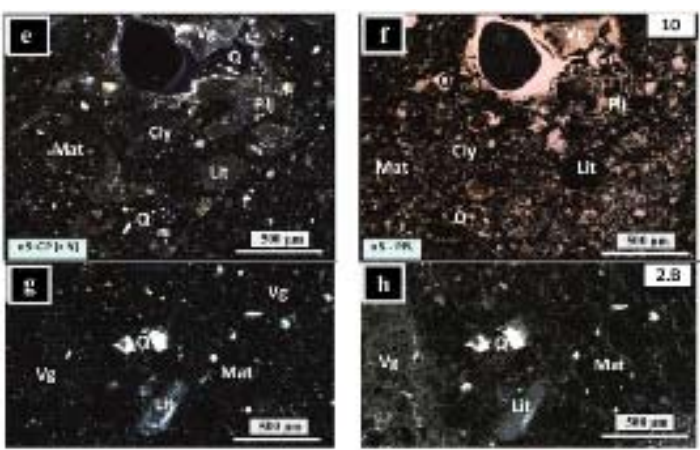

Fig. 2: B. Microphotos of the Gevrekseydi volcanic units and purple opals. 10. Rhyodacitic tuff, 2.B: Purple Opal (Q: Quartz, PI: Plagioclase, Cly: Clay minerals, Vg: Volcanic glass and glass fragments, Mat; Matrix, Lit: Litic materials) 
The XRD patterns of the common opals formed from magmagenetic hydrothermal dissolutions show the presence of more than one pseudo-crystalline phase: opal-CT, containing disordered \pm -cristobalite, and a disordered stacking of sub-equal amounts of cristobalite and tridymitelike layers that were formed in relatively low temperature environments (SANDERS 1975, KASTNER et al. 1977, SANDERS \& MURRAY 1978, NAGASE \& AKIZUKI 1997, CAUCIA et al. 2013). However, in the literature, the constituents of opalCT are often expressed as opal-T and opal-C, to separate them from the real crystalline phases (JONES \& SEGNIT 1971, 1972). Therefore, the opals derived from the magmagenetic dissolutions are generally classified as pseudo-, quasi-, para- or micro-crystalline (KOIVULA 1984, GRAETSCH \& FLÖRKE 1991, KAMMERLING \& FRYER 1994, NAGASE \& AKIZUKI 1997, POP et al. 2004, HATIPOGLU 2009, 2010). Thus, while opal-CT and opal-C are mentioned as pseudo-crystalline, opal$A$ is non-crystalline. The XRD pattern of opal-CT generally results in peaks reflecting both the cristobalite and tridymite-like layers. In the current opal terminology, the term opal-C represents disordered \pm -cristobalite with $20-30 \%$ tridymite-like layers, the term opal-CT represents very disordered \pm -cristobalite with $\sim 50 \%$ tridymite like layers. In the literature, opals made of tridymite-like layers have been called opal-T. However, no separate opal-T was observed in the XRD patterns of the Gevrekseydi purple opals. The broad peak at $\sim 4.1$

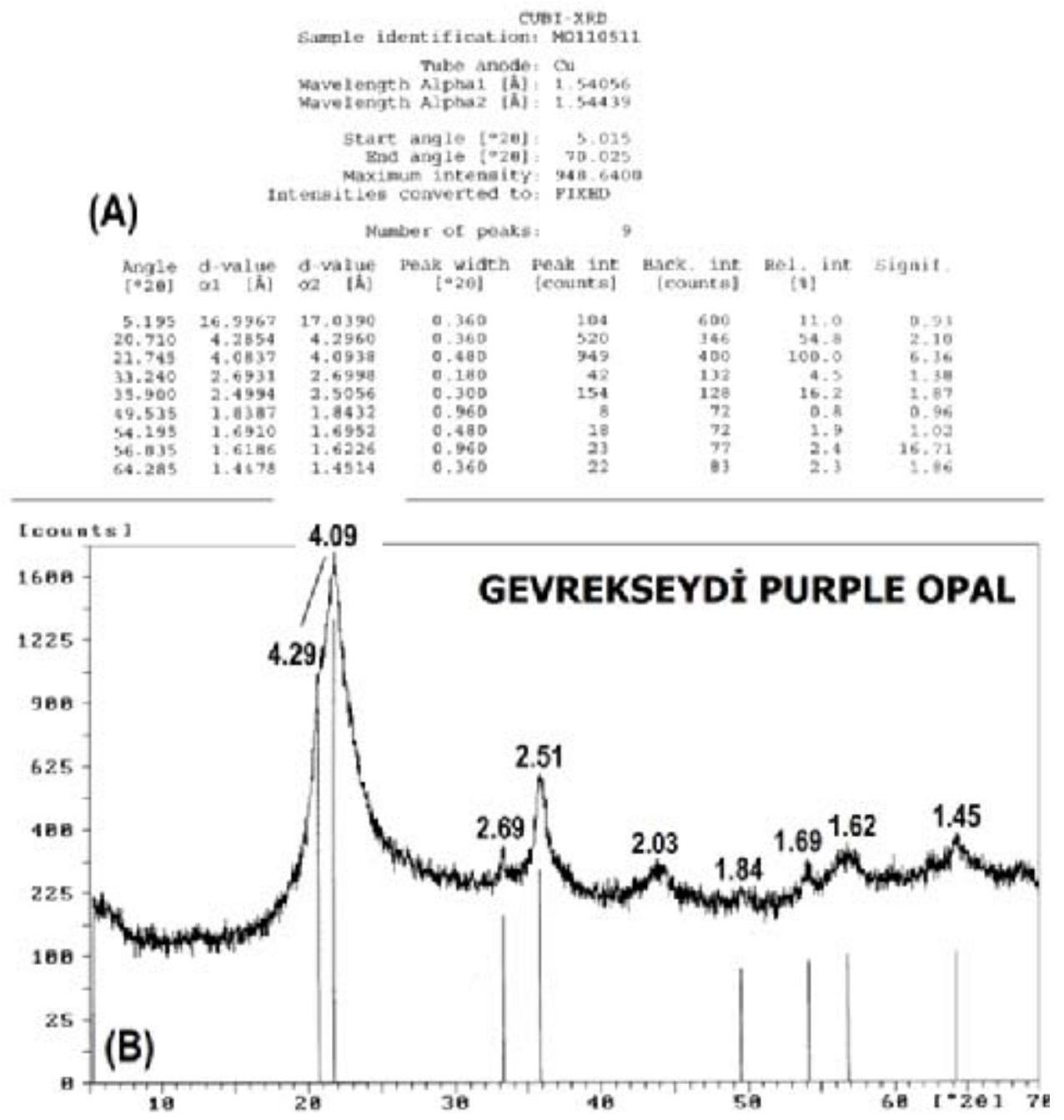

Fig. 3: X-ray diffraction numerical data (A) and pattern (B) of the Gevrekseydi common purple opal 


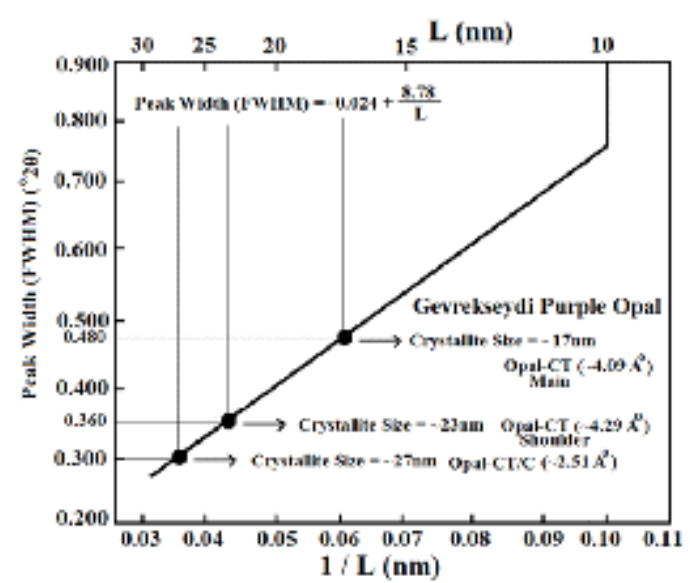

Fig. 4: Relations between crystallite size (L) and width value of the peak at $\sim 35.9^{\circ} 2 \theta$, which represents the main peak of opal-C ( $d$-value $=-2.5$ A) of the Gevrekseydi common purple opals [FullWidth Half-Maximum (FWHM) value of at -35.9²0], (modified from GUTHRIE et al. 1995)

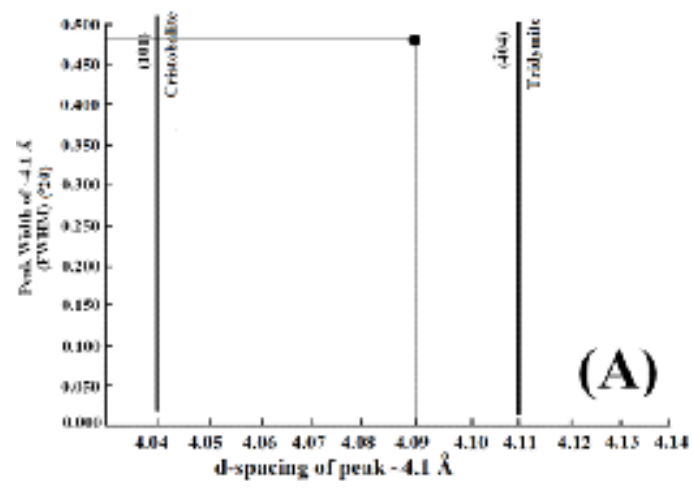

Gevrekseydi Purple Opal

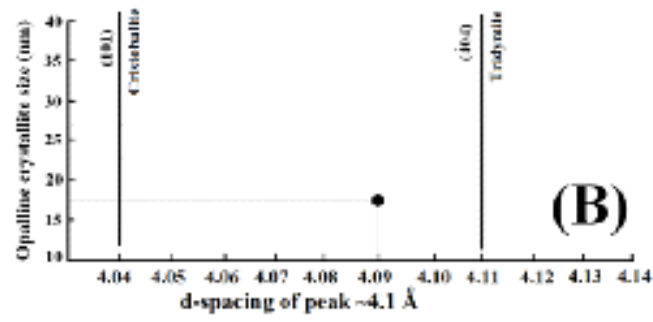

Fig. 5: Modelling the sharpness and broadening of opal-CT by plotting the peak width $\left({ }^{\circ} 2 \theta\right)$ [FullWidth Half-Maximum (FWHM)] (A), and the opaline crystallite size $(\mathrm{nm})(B)$ against the principle d-spacing values $(\AA)$ of the opal-CT peaks obtained from XRD patterns of the Gevrekseydi common purple opals (modified from ELZEA \& RICE 1996)
$\AA$ is present in both opal-C (4.05 $\AA$ ) and opal-T (4.107 $\AA$ ). The peaks observed on the shoulders of the $4.1 \AA$ peak at $4.328 \AA$ and $3.818 \AA$ are attributed to opal-T (SANDERS 1975, FLÖRKE et al. 1976, KANO 1982, FLÖRKE et al. 1991, GRAETSCH 1994, GRAETSCH et al. 1994, GUTHRIE et al. 1995, DE PABLO-GALAN 1997, SMITH 1997, 1998, NAGASE \& AKIZUKI 1997, FRITSCH et al. 2002, ESENLI et al. 2003, LYNNE \& CAMPBELL 2003, BERMANEC 2004, GAILOU \& MOCQUET 2004, FRITSCH et al. 2004, RONDEAU et al. 2004,).

The XRD pattern evaluation, which gives largely qualitative estimates (DE PABLO-GALAN 1997), is the most commonly used method to evaluate crystalline degree, crystallite size, amount of tridymite, interstratifications of cristobalite and tridymite, present crystalline inclusions, relative proportions of cristobalite and tridymite layers, degree of ordered stacking, and site of the $\mathrm{H}_{2} \mathrm{O}$ molecules in the opals (GRAETSCH 1994, GAILOU \& MOCQUET 2004). Two main interpretive techniques were used to evaluate the XRD patterns of the opals; the comparative matching technique, and the graphical modelling technique, the latter of which was modified from SANDERS \& MURRAY 1978, GRAETSCH et al. 1994, GUTHRIE et al.1995, and ELZEA \& RICE 1996.

Crystallinity determination using the comparative matching technique

The observed peaks of the XRD patterns of the purple opal samples were modelled and compared with the XRD patterns reported for pseudo-crystalline opals from different parts of the world using comparative matching (HATIPOGLU $2009,2010)$ to identify the pseudo-crystalline phases in the Gevrekseydi purple opals.

The phase assignments of the XRD peaks for the pseudo-crystalline silica phases of the Gevrekseydi purple opals are given in Table 2. The XRD patterns of the opals represent opal-CT. The d-spacing of the broad diffraction band of opal-CT and associated shoulder are a $4.09 \AA$ (both opal-T and opal-C) peak and a $4.29 \AA$ (opal-T) shoulder. The broad diffraction band between 19 and $24^{\circ} 2_{s}$, which results from the overlap of the [101] from the cristobalite layers at $4.05 \AA$ and the [404] from the interstratified tridymite-like layers at $4.09 \AA$, is called 
opal-CT. Therefore, a characteristic peak at $\sim 4.0 \AA$ $\left(\sim 21.7^{\circ} 2_{s}\right)$ must be observed to demonstrate the presence of opal-CT in pseudo-crystalline opals. Additionally, the main XRD peak at $2.51 \AA\left(\sim 35.8^{\circ} 2_{s}\right)$ is an indicator for the structural ordering and represents the existence of both cristobalite and tridymite layers.

Modelling the crystallite size of the opal matrix Though the width (FWHM) of $2.51 \AA$ peak $\left(\sim 35.9^{\circ} 2_{s}\right)$ of opal-CT/C is primarily sensitive to the

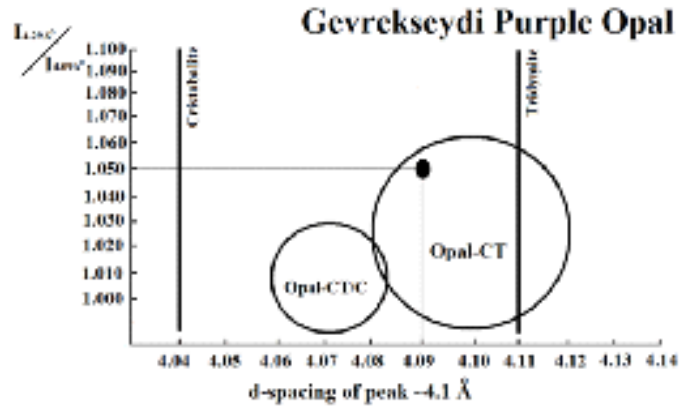

Fig. 6: Modelling the sharpness of opal-CT by plotting the ratio of the principle peak d-spacing of the shoulder peak d-spacing against the principle $d$-spacing values $(\AA)$ of the opal-CT peaks obtained from XRD patterns of the Gevrekseydi common purple opals. The $4.29 \AA$ peak is the main shoulder of the opal-CT peak (4.09 ^̊) (modified from GRAETSCH et al. 1994 and JONES \& SEGNIT 1971). size of the opal crystallites, the main peak widths (FWHM) of opal-CT (d-value $=4.09 \AA$, angle value $=$ $\sim 21.7^{\circ} 2_{s}$ ) and shoulder opal-CT (d-value $=4.29 \AA$, angle value $=\sim 20.7^{\circ} 2_{s}$ ) are also somewhat sensitive to the size of the opal crystallites (ELZEA \& RICE 1996, DE PABLO-GALAN 1997, LYNNE \& CAMPBELL 2003, BERMANEC et al. 2004). The relation between the crystallite size (L) and width values (FWHM) of the opal-CT/C and opal-CT peaks of Gevrekseydi purple opals is given in Fig. 4. Accordingly, the crystallite sizes were found to be $L=17 \mathrm{~nm}$ for main opal-CT, $L=23 \mathrm{~nm}$

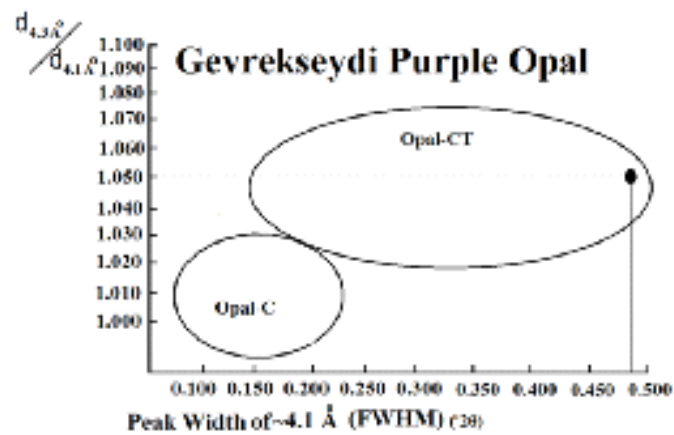

Fig. 7: Modelling the sharpness of opal-CT by plotting the ratio of the principle peak $d$-spacing (A) of the shoulder peak d-spacing ( $(\AA)$ against the principle peak width ( $\left.{ }^{\circ} 2 \theta\right)$ [Full-Width Half-

Maximum (FWHM)] of the opal-CT peaks obtained from XRD patterns of the Gevrekseydi common purple opals. The $\sim 4.3 \AA$ peak is the main shoulder of the $\sim 4.1 \AA$ peak (modified from ELZEA \& RICE 1996; GRAETSCH et al. 1994; JONES \& SEGNIT 1971)

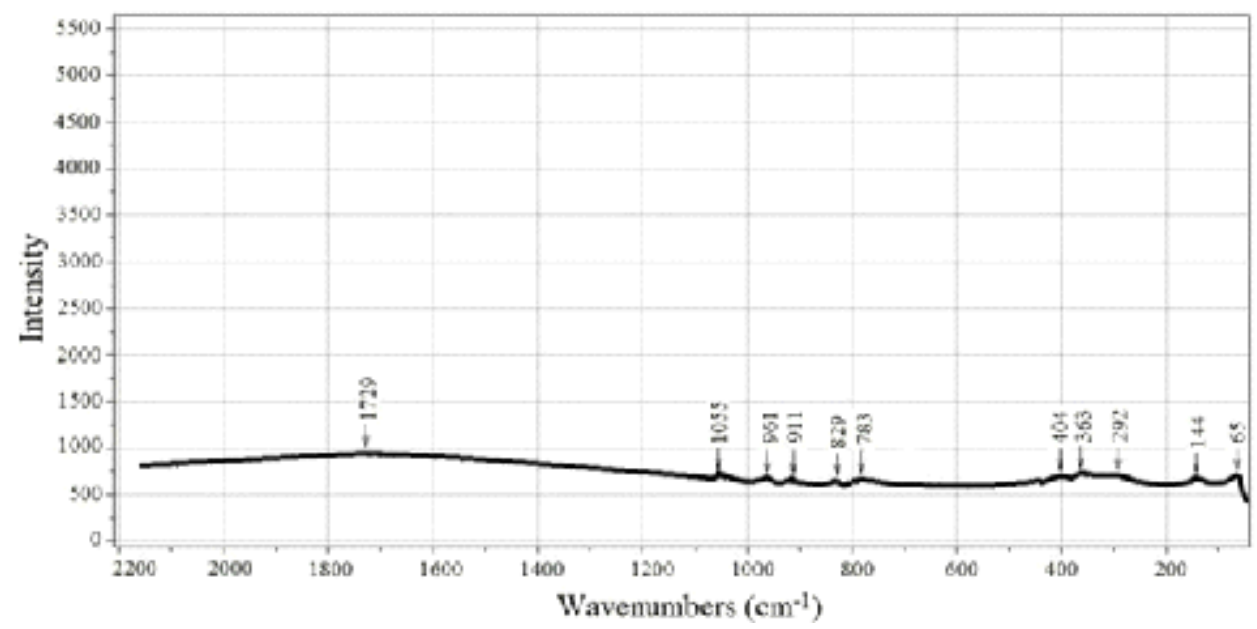

Fig. 8: The confocal micro-Raman spectrum of the Gevrekseydi common purple opal 
for shoulder opal-CT, and L=27 nm for opal-CT/C. These sizes agree with the range of the crystallite sizes of opal-CT and opal-CT/C in other type of opals (e.g., fire opals) that have been previously reported in the literature (KOIVULA \& FRYER 1984, LU et al. 1995, FRITSCH et al. 2004, GAILOU \& MOCQUET 2004, GAILLOU et al.2008, ESENLI, F. \& EKINCI-SANS 2013, RONDEAU et al.2013). The crystallite size for the opals between 11 and $23 \mathrm{~nm}$, which was revealed by modelling XRD patterns, was reported by GUTHRIE et al. 1995. In addition, a crystallite size between 10 and $50 \mathrm{~nm}$ (average $20 \mathrm{~nm}$ ) was obtained using SEM images and AFM by FRITSCH et al. 2004. Guthrie and his colleagues reported that the crystallite size increases as opal-CT's mature. Given the relationship between the increasing crystallite size and maturation of opal-CT, volcano-sedimentary Gevrekseydi common purple opals are likely to reflect an early- to mid-level of maturation (GUTHRIE et al. 1995).

\section{Proportions of cristobalite and tridymite stacking} using the modelling technique

The opal-CT band (between 19 and $24^{\circ} 2_{s}$ ) is sensitive to the relative proportions of the cristobalite and tridymite-like layers, whereas the amount of tridymite present is calculated by modelling the entire diffraction pattern (GUTHRIE et al. 1995). The amount of tridymite obtained by modelling the Gevrekseydi purple opals is given in Table 3. According to this model, a larger peak suggests the presence of more tridymite, $65-70 \%$. Conversely, Ghisoli and his colleagues offered an alternative method for the estimate (GHISOLI et al. 2010). The ratio of tridymite and cristobalite in opaline polymorphs defined as " $\mathrm{C} / \mathrm{T}=\mathrm{d}(4.11)-\mathrm{d}$ (measured) / d(4.11)-d(4.04)". According to this formula, for Gevrekseydi purple opal the $\mathrm{C} / \mathrm{T}=4.11$ 4.09 / 4.11-4.04, and the ratio is $0.29(\mathrm{C} / \mathrm{T}=29 / 71)$. In this case, the Gevrekseydi opal includes approximately $30 \%$ cristobalite and $70 \%$ tridymite, and should be designed opal-CT with disordered structure. Moreover, the tridymite variety in the Gevrekseydi purple opals could form in lowertemperature monoclinic tridymite. If it was in hightemperature tridymite, the shoulder of $4.09 \AA$ peak would be lower than $4.29 \AA$ (FLÖRKE et al. 1975).

\section{Sharpness and breadth of opal-CT peaks using the modelling technique}

The main peak of opal-CT in the XRD patterns of Gevrekseydi purple opals is unusually sharp, giving small crystallite sizes $(17 \mathrm{~nm})$ and relating directly to long-range order of crystallinity (SANDERS \& MURRAY 1978, KANO 1982, GRAETSCH et al 1994, ELZEA \& RICE 1996). Some modelling graphics related to the sharpness of opalCT peaks are given in Figs. 5-7. Gevrekseydi purple opals show the principle d-spacing values at 4.09 $\AA$, and principle $\mathrm{FWHM}$ at $0.480^{\circ} 2$, (Fig. 5A). The peak breadth and sharpness relate to the opaline crystallite size (Fig. 5B). These findings are consistent with the interpretation of Elzea and Rice 1996. In the classification schemes recommended in previous studies (ELZEA \& RICE 1996, RONDEAU et al. 2013), Gevrekseydi purple opals fall into the opal-CT category (Figs. 6 and 7).

\section{Confocal Micro-Raman}

The confocal micro-Raman spectrum of Gevrekseydi purple common opal is given in Fig. 8. In addition, its band assignments and comparisons are listed in Table 4. The representative microRaman spectrum reveals the presence of opal-CT/ C with the characteristic band at $292 \mathrm{~cm}^{-1}$ and the presence of opal-CT with characteristic bands at 363 and $404 \mathrm{~cm}^{-1}$ (KINGMA \& HEMLEY 1994, GÖTZE, et al. 1998, OSTROOUMOV et al. 1999, MCCREERY 2004, POP et al. 2004, OSTROOUMOV 2007, DUMANSKA-SLOWIK et al. 2013). However, some vibration bands in the sample cannot be assigned to the specific molecules. We can state that these bands are due to complex heterogeneous inclusions. The two bands at 65 and $144 \mathrm{~cm}^{-1}$ can be assigned to low quartz found as inclusion in the purple opals. The micro-Raman bands below 1000 $\mathrm{cm}^{-1}$ (such as, at 783, 829, 911, and $961 \mathrm{~cm}^{-1}$ ) indicate the presence of nanocrystalline molecules of $\mathrm{Fe}, \mathrm{Cu}, \mathrm{Ti}, \mathrm{Zn}, \mathrm{Mn}$, and $\mathrm{Pb}$ oxides, as detected in the purple opals. Finally, the presence of carbonaceous matter is marked by 1055 and 1729 cm bands (KINGMA \& HEMLEY 1994, GÖTZE, et al. 1998, POP et al. 2004, DUMANSKA-SLOWIK et al. 2013).

\section{CONCLUSIONS}

1. Gevrekseydi opals are an attractive gemquality common opal. The opals are deposited in the large strata of the volcanic tuffs. However, the main silica source of the opals 
is derived from the underlain rhyodacitic and dacitic rocks, and all of them are called the Gevrekseydi volcanic because of their proximity to the village of Gevrekseydi. The purple opal strata in the Seyitömer (Kütahya) region are genetically associated with magmagenetic hydrothermal activity. This formation is a true dissolution process in which the spheres remain intact, but are dispersed into the gel.

2. Some transition metal elements such as $\mathrm{Cu}$ (2500 ppm), Ti (800 ppm), Zn (317 ppm), Mn (206 ppm), and $\mathrm{Pb}(127 \mathrm{ppm})$ are characteristic of the Gevrekseydi purple opals.

3. The variability in chemical composition, physical properties and micro-textures indicate that the purple opals formed from different solutions at variable growth rates.

4. Individual modelling techniques using X-ray diffraction (XRD) patterns are suitable detection method for determining the crystallite size of the opaline building phases, as confirmed by the scanning electron microscope (SEM) images and atomic force microscope (AFM) graphics.

5.. The degree of crystallinite of the Gevrekseydi common purple opals was interpreted. The opals have a nano-structure at crystallite sizes between 10 and $50 \mathrm{~nm}$ comprising cristobalite and tridymite stacking sequences according to the type of opal (precious, common or hyalite) and its origin (sedimentary or volcanic rocks, or volcaniclastic sediments). The crystallite size of the main opaline building phase (opal-
CT) in the Gevrekseydi opals is $17 \mathrm{~nm}$. This value indicates a relatively small crystallite size and porosity that is filled with the molecular and silanol waters in opal texture. Accordingly, we can state that the pores in the "volcano-sedimentary" common opals are smaller and of more uniform size compared with those found in "sedimentary and volcanic" common opals.

6. There is no evidence for the presence of any accessory minerals in the Gevrekseydi purple common opal.

7. The band assignments and comparisons of the Opal-CT and opal-CT/C in the confocal micro-Raman spectrum of the Gevrekseydi purple common opal are presented. The Raman bands reveal many silica inclusions, transition metal oxides and carbonaceous matters in the Gevrekseydi purple opals.

8. Further investigations on the Gevrekseydi opals with various body colors would be desirable FT-IR analyses would be particularly interesting, and could indicate the gneiss of this type of opal formations.

\section{ACKNOWLEDGEMENTS}

We would like to express our gratitude and special thanks to three anonymous reviewers and to Prof.Dr. Fahri ESENLI-Istanbul Technical University- for the useful comments and suggestions on the interpretation of our draft manuscript. We appreciate their time and effort in helping to revise this manuscript and greatly value their assistance, valuable comments and language corrections.

\section{REFERENCES}

1. Akkiraz, M.S., Akgün, F., Utescher, T., Wilde, W., Volker-Bruch, A.A.,, Mosbrugger, V. \& Ucbas, S.D.,, Palaeoflora and Climate of Lignite-bearing Lower"Middle Miocene Sediments in the Seyitömer and Tunçbilek Sub-basins, Kütahya Province, Northwest Turkey. Turkish Journal of Earth Sciences, 2012; 21, 213-235.

2. Arem, J.E. : Color Encyclopaedia of Gemstones, $2^{\text {nd }}$ Ed. Van Nostrand Reinhold. Co., New York, 1987, 675.
3. Back, M. \& Mandariona, J., Fleischer's Glossary of Mineral Species; $10^{\text {th }}$ ed. The Mineralogical Record, Inc., Tucson, 2008, 342.

4. BAs, H., Domaniç-Tavsanli-Kütahya-Gediz yoresinin Tersiyer Jeolojisi. Jeoloji Muhendisligi Dergisi, 1986; 27, 11-18.

5. Bermanec, V., Tomasic, N., Karfunkel, J., Scholz, R., Kniewald, G. \& Jaksch, H., Nanocrystals of tridymite in opal cavities, in: Proceedings 8th International Congress on 
Applied Mineralogy, Aguas De LindoiaBrazil, 2004, 525-527.

6. Caucia, F., Marinoni, L. \& Leone, A., Physical, geochemical and gemological properties of opals from Faroe Islands. Neues Jahrbuch fur Mineralogie-Abhandlungen, 2013; 191, 33-43.

7. De Pablo-galan, L., De Laurdes Chavezgarcia, M. \& Huanosta Tera, A., Electrical properties of opal-CT. Physics and Chemistry of Minerals, 1997, 24, 90-101.

8. Dodony, I. \& Takacs, J., Structures of precious opal from Cervenica. Ann. Univ. Sci. Budap. Rolando Eotvos Nominatae, Sect. Geol., 1980, 22, 37-50.

9. Dumanska-Slowik, M., Natkaniek-Nowak, L., Waselucha-Birczynska, A., Gawel, A., Lankosz, M. \& Wrobel, P., Agates from Sidi Rahal, in the Atlas Mountains of Morocco: Gemological characteristics and proposed origin. Gems \& Gemology, 2013; 49, 148159.

10. Elzea, J.M. \& Rice, S.B., TEM and X-ray diffraction evidence for cristobalite and tridymite stacking sequences in opal. Clays Clay Minerals, 1996, 44, 492-500.

11. Elsass, F., Dubroeucq, D. \& Thiry, M., Diagenesis of silica minerals from clay minerals in volcanic soils of Mexico. Clay Minerals, 2000, 35, 477-489.

12. Elzea, J.M. \& Rice, S.S.: TEM and X-ray diffraction evidence for cristobalite and tridymite stacking sequences in opal. Clays and Clay Minerals, 1996, 44, 492-500.

13. Esenli, F., Kumbasar, I., Esenli, V. \& Kirikoglu S., A study on the characteristics of some opals from Turkey. Neues Jahrbuch für Mineralogie Mh., 2003, 4, 177-192.

14. Esenli, F. \& Ekinci-Sans, B., XRD studies of opals (4 A peak) in bentonites from Turkey; Implications for the origin of bentonites. Neues Jahrbuch für MineralogieAbhandlungen, 2013, 191, 45-53.

15. Flörke, O.W., Jones, J.B. \& Segnit, E.R., OpalCT crystals. Neues Jahrbuch für MineralogieAbhandlungen, 1975, 8, 369-377.

16. Flörke, O.W., Hollmann, R., Rad, U. \& Rösch, $\mathrm{H}$., Intergrowth and twinning in opal-CT lepispheres. Contribution to Mineralogy and Petrology, 1976, 58, 235-242.
17. Flörke, O.W., Graetsch, H., Martin, B., Röller, K., Wirth, R., Nomenclature of micro- and noncrystalline silica minerals, based on structure and microstructure. Neues Jahrbuch für Mineralogie-Abhandlungen, 1991, 163, 1942.

18. Fritsch, E., Gem News: Fine greenish-blue opal. Gems \& Gemology, 1991, 27, 120-121.

19. Fritsch, E., Ostrooumov, M., Rondeau, B., Barreau, A., Albertini, D., Marie, A.M., Lasnier, B. \& Wery, J., Mexican gem opal: nano- and micro-structure, origin of colour and comparison with other common opals of gemmological significance. The Australian Gemmologist, 2002, 21, 230- 233.

20. Fritsch, E., Gaillou, E., Ostroumov, M., Rondeau, B., Devouard B. \& Barreau, A., Relationship between nanostructure and optical absorption in fibrous pink opals from Mexico and Peru. European Journal of Mineralogy, 2004, 16, 743-752.

21. Gailou, E. \& Mocquet, B., A new gem material from Madagascar: A mixture of cristobalite and opal. Gem \& Gemology, 2004, 40, 339340.

22. Gaillou, E., Fritsch, E., Aguilar-reyes, B., Fondeau, B., Post, J. Barreau, A. \& Ostroumov, M., Common gem opal: An investigation of micro- to nano-structure. American Mineralogist, 2008, 93, 1865-1983.

23. Ghisoli, C., Caucia, F. \& Marinoni, L., XRPD patterns of opals: A brief review and new results from recent studies. Powder Diffraction, 2010, 25, 274-282.

24. Götze, J., Nasdala, L., Kleeberg, R. \& Wenzel, M., Occurrence and distribution of "moganite" in agate/chalcedony: a combined micro-Raman, Rietveld, and cathodoluminescence study. Contributions to Mineralogy and Petrology, 1998, 133, 96105.

25. Graetsch, H. \& Flörke, O.W., X-ray powder diffraction patterns and phase relationship of tridymite modifications. Zeitschrift fur Kristallographie, 1991, 195, 31-48.

26. Graetsch, H., Structural characteristics of opaline and microcrystalline silica minerals. Reviews in Mineralogy, 1994, 29, 209-232.

27. Graetsch, H., Gies, H. \& Topolovic, I.., NMR, $\mathrm{XRD}$, and, IR study on microcrystalline opals. 
Physics and Chemistry of Minerals, 1994, 21, 166-175.

28. Guthrie, G.D., Bish, D.I., \& Reynolds, R.C., Modelling the X-ray diffraction pattern of opal-CT. American Mineralogist, 1995, 80, 869-872.

29. Gübelin, E.J., Opal from Mexico. The Australian Gemmologist, 1986, 16, 45-51.

30. Hatipoglu, M., Moganite and quartz inclusions in the nano-structured Anatolian fire opals from Turkey. Journal of African Earth Sciences, 2009, 54, 1-21.

31. Hatipoglu, M., The nano-grain sizes of the opalline matrix components in Anatolian fire opals. Journal of Non-Crystalline Solids, 2010, 356, 1408-1415.

32. Jones, J.B. \& Segnit, E.R. The nature of opal. Part I. Nomenclature and constituent phases. Journal of the Geological Society of Australia 1971, 18, 57-68.

33. Jones, J.B. \& Segnit, E.R., Genesis of cristobalit and trydimite at low temperatures. Journal of the Geological Society of Australia, 1972, 18, 419-422.

34. Kalafatcooglu, A., Tavsanli-Dagardi Arasindaki bölgenin jeoloji ve serpantin ile kalkerlerin yasi hakkinda not. Bulletin of M.T.A. Ankara, 1962, 58, 34.

35. Kammerling, R.C. \& Fryer, C.W., Gem news: Opal translucent greenish blue. Gems \& Gemology, 1994, 30, 43-44.

36. Kano, K.., \& Taguchi,, K. Experimental study on the ordering of opal-CT. Geochemical Journal, 1982, 16, 33-41.

37. Kastner, M., Keene, J.B., \& Gieskes, J.M., Diagenesis of siliceous oozes-I. Chemical controls of the rate of opal-A to opal-CT transformation. An experimental study. Geochimica and Cosmochimica Acta, 1977, 41, 1041-1059.

38. Kingma, K.J. \& Hemley, R.J., Raman spectroscopic study of microcrystalline silica. American Mineralogist, 1994, 79, 269-273.

39. Koivula, J.I. \& Fryer, C.W. , Green opal from East Africa. Gems \& Gemology, 1984, 20, 226-227.

40. Koivula, J.I. , Kammerling, R.C. Gem news: Fine greenish blue opal. Gems \& Gemology, 1991; 27,120-121.

41. Leechman, F., The Opal Book; $5^{\text {th }}$ Ed. Ure
Smith, Lansdowne Press, Sidney, 1975, 264.

42. Lebküchner, R.F., Linyit Bulunmasi Muhtemel Ayvali (Kütahya) sahasýnda yapilan jeolojik ve madencilikle ilgili etüdlerin neticesi hakkinda rapor. M.T.A. Report No: 2984, Ankara (unpublished), 1957.

43. Lebküchner, R.F., Seyitömer-Kütahya Neojen sahasýnda jeoloji ve linyit yataklarý ile ilgili olarak yapýlan etüdler hakkýnda rapor: M.T.A. Report No: 2985, Ankara (unpublished), 1959.

44. LU, T., Zhang, X., Sunagawa, I. \& Groves, G.W., Anometre scale texture in agate and Beltane opal. Mineralogical Magazine, 1995, 59, 103-109.

45. Lynne, B.Y. \& Campbell, K.A., Diagenetic transformation (opal-A to quartz) of low- and mid-temperature microbial textures in siliceous hot-spring deposits, Taupo Volcanic Zone, New Zealand. Canadian Journal of Earth Sciences, 2003, 40, 1679-1696.

46. MC CREERY, R.L., Raman spectroscopy for chemical analysis. In: Winefordner JD (ed), Chemical Analysis: A series of monographs on analytical chemistry and its applications, John Wiley \& Sons, New York, 2004, 448.

47. Monroe, E.A. Sass, D.B., \& Cole, S.H., Stacking faults and polytypism in opal, SiO2nH2O. Acta Crystalografica, 1969, A25, 578-580.

48. Nagase, T. \& Akizuki, M., Texture and structure of opal-C in volcanic rocks. Canadian Mineralogist, 1997, 35, 947-958.

49. Nebert, K., Tunçbilek Havzasinin (Kütahya) detay jeolojik lövelere dayanan montan jeolojik durum hakkýnda rapor. M.T.A. Report No: 3002, Ankara (unpublished), 1961.

50. Okay, A., The geology and blueschist metamorphism of the ophiolites in Northwest Turkey (Tavsanli-Kutahya). Türkiye Jeoloji Kurumu Bülteni, (in Turkish with English Abstract), 1981, 24, 85-95.

51. Ostrooumov, M., Fritsch, E., Lasnier, B., \& Lefrant, S., Raman spectra of opals: Diagnostic aspect and classification tool. European Journal of Mineralogy, 1999, 11, 899-908.

52. Ostrooumov, M., A Raman, infrared and XRD analysis of the instability in volcanic opals from Mexico. Spectrochimica Acta Part A, 
2007, 68, 1070-1076.

53. Özburan, M. \& Gürer, Ö.F., Late Cenozoic polyphase deformation and basin development, Kütahya region, western Turkey. International Geology Review, 2011, 54: 1401-1418.

54. Özgenç, I. \& Ilbeyli, N., Petrogenesis of the Late Cenozoic Egrigöz pluton in western Anatolia, Turkey: implications for magma genesis and crustal processes. International Geology Review, 2008, 50, 375-391.

55. Pop, D., Constantina, C., Tatar, D. \& Kiefer, W., Raman spectroscopy on gem-quality microcrystalline and amorphous silica varieties from Romania. Studia Universitatis babe-Bolyai Geologia, 2004, 49, 41-52.

56. Pretola, J.P., A feasibility study using silica polymorph ratios for sourcing chert and chalcedony lithic materials. Journal of Archaeological Science, 2001, 28, 721-739.

57. Rondeau, B., Fritsch, E., Guiraud, M. \& Renac, C., Opals from Slovaks ("Hungarian" opals): a re-assessment of the conditions of formation. European Journal of Mineralogy, 2004, 16, 789-799.

58. Rondeau, B., Gauthier, J-P., Mazzero, F., Fritsch, E., Bodeur, Y. \& Chauvire, B., On the origin of Digit patterns in gem opal. Gems \& Gemology, 2013, 49, 138-146.

59. Rossman, G.R., Colored varieties of the silica minerals. Silica: Physical Behavior. Geochemistry and Materials Applications, 1994, 29, 433-467.

60. Sanders, J.V., Microstructure and crystallinity of gem opals. The American Mineralogist, 1975, 60, 749-757.
61. Sanders, J.V. \& Murray, M.J., Ordered arrangements of spheres of two different sizes in opal. Nature, 1978, 275, 201-203.

62. Sanders, J.V., Jelly opal from White Cliffs. The Australian Gemmologist, 1981, 14, 161 168.

63. Sariyildiz, M., Seyitömer (Kütahya) KB'sindeki kömürlü Neojen kayalarýn jeolojisi [Geology of Neogene Rocks in NW of Seyitömer (Kütahya)]. MSc Thesis, Dokuz Eylül University, Geology Dept., Izmir, Turkey (Unpublished), 1987, 153.

64. Smith, D.K., Evaluation of the detectability and quantification of respirable crystalline silica by X-ray powder diffraction. Powder Diffraction, 1997, 12, 200-227.

65. Smith, D. K., Opal, cristobalite, and tridymite; noncrystallinity versus crystallinity nomenclature of the silica minerals and bibliography. Powder Diffraction, 1998, 13, 2-19.

66. Turkmenoglu, A.G. \& Yavuz-Isik, N., Mineralogy, chemistry and potential utilization of clays from coal deposits in the Kütahya province, Western Turkey. Applied Clay Science, 2008, 42, 63-73.

67. Vicil, M., Gümüsköy (Kütahya) Aktepe PbZn- Sb-Ag cevherlesmesi. PhD Thesis, Ege University, Geology Dept., Izmir, Turkey (Unpublished), 1982, 258p.

68. Yanik, G., Seyitömer (Kütahya) kömür Havzasi Killerinin Jeolojisi, Mineralojisi Ve Seramik Endustrisindeki Kullanim Olanaklari. Msc Thesis, Dumlupinar University, Kütahya, Turkey (Unpublished), 1997, 89. 